\title{
The Changes and Development of Financial Accounting Theory and Practice in the E-commerce Era
}

\author{
Xiaotian Zhang \\ Chinese People's Armed Police Force Non-commissioned Officer School, Hangzhou 310023, Zhejiang, China \\ Email:944173202@qq.com
}

\begin{abstract}
The roadmap of financial accounting in the era of sustainable development of e-commerce may help organizational accounting methods to achieve sustainable development. Based on the author's learning and practical experience, this article aims to provide ideas for further financial accounting research, so that the industry can pay attention to the impact of changes in the situation on financial accounting and make corresponding changes.
\end{abstract}

Keywords: financial accounting, e-commerce, theory and practice, change and development

\section{Introduction}

The emergence of e-commerce is not only a technological change, but also created a socio-economic environment of automation, networking, digitization, and virtualization ${ }^{[1]}$. Economic accounting is a whole, represented by the so-called input-output table. Input-output tables allow the integration of business accounts with national accounts. They can capture the supply of all goods and services (including domestic production and imports from other countries) and the subsequent use of these products (whether it is other industries in the intermediate consumption economy, or the final Consumer family, government or other countries). The input-output table not only provides an overview of the interaction between producers and consumers, but is also the basis for estimating a country's gross domestic product (GDP). The accounting department is playing an increasingly important role in the enterprise integrated management information system. In addition to mastering accounting skills, accountants must also have computer, e-commerce, management and legal knowledge ${ }^{[2]}$. For the financial accounting industry to maintain its relevance, it must participate more effectively in other professional disciplines and pay attention to the challenges of sustainable development.

Internationally operating e-commerce companies, as well as e-commerce companies created as a joint stock company, shape the company's financial accounting policies and apply financial accounting diversification in accordance with the International Financial Reporting Standards. The standard aims to improve the appropriateness and authenticity of a company's financial statements, improve the comparability of the financial accounting, and compare it with the financial statements of other companies. In addition, if e-commerce companies adopt innovative methods to operate, the diversification of accounting may be related to e-commerce companies. Examples of this are: the use of cryptocurrency payments or unmanned aircraft to deliver to customers; the automation of related business processes such as parcel sorting, parking lot replenishment, and electric vehicle distribution. E-commerce companies may have illegal activities in the course of their business activities, which is due to the implementation of cyber crimes. In the process of financial accounting organization, certain obstacles can be set up as a method to prevent cybercrime. The research analyzes the influence of the financial accounting policy elements provided in the current legislation, and determines the financial accounting policy elements that need to be included in the financial accounting policy administrative documents of e-commerce enterprises.

\section{The influence of the development of e-commerce on traditional financial accounting}

\subsection{Impact on financial accounting theory}

Accounting installments are greatly affected by e-commerce, so the accrual system is also affected accordingly. The premise of contingency economics and political economics is that the trajectory followed by the organizational background transcends the particularity of corporate characteristics. For its part, progress has given organizations a control method that is similar to the homogenization effect of industrial change. The impact of convergence is reflected in the interdependence of technology, market, strategy, labor and other background variables with the replication of organizational structure, and organizational structure is the basis for controlling change. These academic explanations on the operation of organizational control are based on the assumptions about the stability of the relationship between environmental characteristics and organizational characteristics and processes (including financial accounting management methods). 
Considering that e-commerce accounting is fully automated, companies will automatically lose some elements of alternative accounting policies. E-commerce companies use the cost-determined inventory release assessment method to determine inventory disposal costs; the analysis of inventory accounting units is based on their names. Since the goods sold to customers are subscription-based, the method of calculating doubtful debt reserves is not always a necessary factor in accounting policies. The elements of the financial accounting policy are: to facilitate the reimbursement of expenses and payments; to pay vacation leave for the employees of the enterprise; to provide for additional pensions, etc. It is one of the tasks of financial accounting services to provide the development of financial accounting methods for the specific business of e-commerce enterprises. It can be done by creating the form of the main document. In the process of formulating financial accounting policies, increase the analytical accounting of the second or third-level accounting, and choose an alternative accounting plan from the current legislation. If there is enough information about specific accounting objects in the existing legislation, it is possible to establish financial accounting method regulations for business transactions specific to e-commerce at the corporate level. For example, it provides a method for the bookkeeping of business activities related to the development of the website, which can be maintained at the level of commercial entities, since the main points related to the identification and evaluation of the financial accounting costs of site construction are determined by the current legislation .

\subsection{Impact on financial accounting practice}

Financial accounting and financial statements can be made online. The availability and convenience of the network are more conducive to financial accounting information users to make correct decisions, thereby affecting the work of traditional financial accounting statements. Considering the international nature of most companies engaged in e-commerce, it should be pointed out that they use the legislation of countries that provide more convenient conditions for doing business. Based on the principled change of world perception in the information economy, due to the transition from the principle of global determinism to the principle of self-organized criticality, improved methods are required to predict economic phenomena and processes. Need to apply methods to forecast the development of financial accounting. Based on this fact, it is a complex and dynamically developing system. In order to forecast the medium and long-term development of financial accounting, intuitive and professional methods and non-linear system forecasting methods are used. Short-term forecasts must use formal or mathematical forecasting methods.

The content of the financial accounting policy regulatory documents reflects the diversified financial accounting of a specific e-commerce company. The second aspect of diversified financial accounting is embodied in the formation of accounting policies for e-commerce companies to keep accounts in accordance with International Financial Reporting Standards. These aspects do not violate applicable legislation and are within the legal framework. The third aspect of diversified financial accounting is the use of certain flaws in existing legislation or electronic crimes caused by end-consumer confidence. In some cases, electronic crimes can be prevented through preventive measures created in the financial accounting system.

\section{Countermeasures to strengthen financial accounting work in the e-commerce era}

\subsection{Improvement of financial accounting functions}

Traditional financial accounting work is very limited, it is only financial accounting and supervision audit based on financial accounting events. However, the financial accounting function has undergone great changes and improvements in the e-commerce environment. Financial accounting can be achieved through the Internet and computers. The financial accounting work coordinates the management of various departments, suppliers and the government, so the coordination role is clear. Theft of user information is usually carried out by taking advantage of his excessive credulity and misleading. Therefore, it is impossible to prevent such electronic crimes with the help of accounting system tools. Preventing unauthorized interference with computer systems can be carried out with the help of preventive measures developed by enterprise information security services. Preventing cybercrime is an important aspect of the successful operation of e-commerce enterprises. The consequences of cybercrime have a negative impact on a company's reputation and reduce customer loyalty. By improving the content of individual internal regulations (the work instructions of accountants who control settlements between e-commerce and end users), and using the information and control functions of financial accounting, cyber crime prevention measures can be established in the bookkeeping system.

\subsection{Changes in the financial accounting organization}

Financial accounting work can often be achieved through the Internet and computers, which makes the design of traditional financial accounting positions a decoration, requiring adjustment or consolidation of financial accounting positions. In the environment of e-commerce, a financial accountant is not only an excellent accountant, but also should be 
proficient in computer skills and master various software operations, so as to adapt to the new requirements of e-commerce for financial accountants. The dialectical method can establish the status and importance of bookkeeping to e-commerce companies, and determine the problems, adaptation and improvement directions in the context of the integration of the national economy into the global economic space. Modern interpretation methods for evaluating the elements of accounting methods are used. In the process of studying the economic achievements of the modern world, historical and logical methods are combined with the determination of the characteristics of e-commerce enterprise activities and their evolution stages. Through analysis and comprehensive methods, a conclusion is drawn on the necessity and possibility of practical application of the research results.

\subsection{Changes in the concept of financial accountants}

Financial accountants must not only change the way of thinking after the event in the past, but also have risk awareness and forward-looking thinking. In this way, they can be more competent in the financial accounting work under the e-commerce environment. Secondly, with the continuous changes of the financial accounting environment, there are more and more risks and uncertainties in the financial accounting work. This requires financial accounting personnel to fully understand this phenomenon, be psychologically prepared, always use a dynamic and forward-looking vision to manage financial accounting work, and do their utmost to reveal and control financial accounting risks.

In the context of digitalization, a qualitative reassessment of financial accounting management is required. In a rapidly transforming digital economy, emerging business models cannot assume the stability of relationships. Now there is a need to question the applicability of quantitative methods. These methods have been used to study the analog organization environment of the linear arrangement of information systems, and their continued applicability under the changing process structure of the digital enterprise environment should also be considered. This question transcends the legitimacy of using quantitative research norms extracted from pure science to qualitative investigations. For financial accounting management scholars, this change in financial accounting control provides many research opportunities. A descriptive survey was conducted on the management financial accounting techniques adopted by the enterprise. This survey reports the use of standard technologies and determines the similarities and differences in adoption rates among companies, industrial sectors, and geographic regions, but does not necessarily explain the basis of the reported differences ${ }^{[4]}$. Descriptive management financial accounting practice literature reports many standard techniques used in companies, such as costing, cost allocation, budget control practices, variance analysis, standard costing, pricing techniques, capital budgeting methods, and transfer pricing methods.

\section{Conclusion}

The research in this paper shows that the financial accounting policies of e-commerce companies should be consistent with the main guidelines for their development and economic activity characteristics. E-commerce enterprise financial accounting supervision documents (accrual method of intangible assets and fixed assets, method of evaluating stock sales, etc.) should be formulated, and the development strategy of e-commerce enterprise should be considered.

\section{References}

[1] Liu Hui. Research on the Innovation and Development of Enterprise Financial Accounting Work in the Information Age[J]. Market Modernization, 2020(15): 183-185.

[2] Yin Tao. Research on Enterprise Financial Management in the E-commerce Era[J]. Public Investment Guide, 2019(23): $63+65$.

[3] Liu Jun. Research on the Development of Network Financial Accounting in the E-commerce Era[J]. Taxation, 2018, 12(27): $127+129$.

[4] Zhang Hongying. Research on the development of financial accounting under e-commerce[J]. Chinese Market, 2017(25): 161-162. 